\title{
ZIELEŃ PRZYWODNA W ZAGOSPODAROWANIU PARKU ZA SZKOŁĄ MORSKĄ W DARŁOWIE
}

\author{
GREENERY LEADING IN THE PARK DEVELOPMENT BEHIND THE MARITIME \\ SCHOOL IN DARŁOWO
}

\section{PaweŁ SzumigaŁa, Piotr Urbański, RafaŁ Siwiński, MiŁosz Walerzak, Karolina SzumigaŁa}

\begin{abstract}
R. Siwiński, A.K.T.Z. Panderoza S.C., Popowo 49 A, 64-100 Wronki, Poland, e-mail: rafal.maria.siwinski@gmail.com

K. Szumigała, studentka Wydziału Architektury Politechniki Poznańskiej, ul. Nieszawska 13, 61-021 Poznań, Poland, e-mail: karolina.szumigala@wp.pl

P. Szumigała, Katedra Terenów Zieleni i Architektury Krajobrazu, Uniwersytet Przyrodniczy w Poznaniu, ul. Dąbrowskiego 159, 60-594 Poznań, Poland, e-mail: pawel.szumigala@up.poznan.pl

P. Urbański, Katedra Terenów Zieleni i Architektury Krajobrazu, Uniwersytet Przyrodniczy w Poznaniu, ul. Dą̧browskiego 159, 60-594 Poznań, Poland, e-mail: piotr.urbanski@up.poznan.pl

M. Walerzak, Katedra Terenów Zieleni i Architektury Krajobrazu, Uniwersytet Przyrodniczy w Poznaniu, ul. Dąbrowskiego 159, 60-594 Poznań, Poland, e-mail: milosz.walerzak@up.poznan.pl
\end{abstract}

(Received: February 2, 2018. Accepted: March 3, 2018)

\begin{abstract}
The article presents the issues related to the use of greenery in the desing of public spaces on the example of the development project of the park behind the Maritime School in Darłowo. Composition, natural and environmental issues concerning a selected part of the park, i. e, the zone of leading greenery in the vicinity of the former city moat, were discussed. The presented implemention are arguments the basis for recreating in this part of the park as a landscape with natural values of historical space.
\end{abstract}

KEY WORDS: greenery, land development, park, Darłowo

\section{WSTĘP}

Park za Szkołą Morską jest zlokalizowany w niedużej odległości od Zamku Książąt Pomorskich w Darłowie, w kierunku południowo-zachodnim (ryc. 1). Teren od strony wschodniej sąsiaduje z centralną, śródmiejską strefą miasta. Na obszarze parku znajdują się fragmenty historycznych fortyfikacji ziemnych oraz fragment fosy miejskiej usytuowanej po południowej stronie fortyfikacji. Fosa jest zasilana w wodę z rzeki Wieprzy przepływającej po zachodniej stronie fortyfikacji.

1 Miejscowy plan zagospodarowania przestrzennego miasta Darłowo - uchwała nr XLVII/445/06 Rady Miejskiej w Darłowie z dnia 27 marca 2006 r. Resolution
Projektowanie na terenach historycznych struktur przestrzennych wiąże się z koniecznością uwzględniania wielu wymagań, głównie planistycznych ${ }^{1}$ i konserwatorskich ${ }^{2}$.

Należy także brać pod uwagę zapotrzebowanie społeczne na obszary wypoczynku i rekreacji. Spełnienie tych warunków w projekcie planu zagospodarowania parku było możliwe dzięki zastosowaniu

No. XLVII/445/06 of the Council having regard to the conclusions of the meeting of 27 march 2006 of the City of Darłowo on the implementation of the Community Strategy for Urban Development.

2 Wytyczne Wojewódzkiego Konserwatora Zabytków w Koszalinie. Guidelines of the Voivodship Conservator of Monuments in Koszalin. 

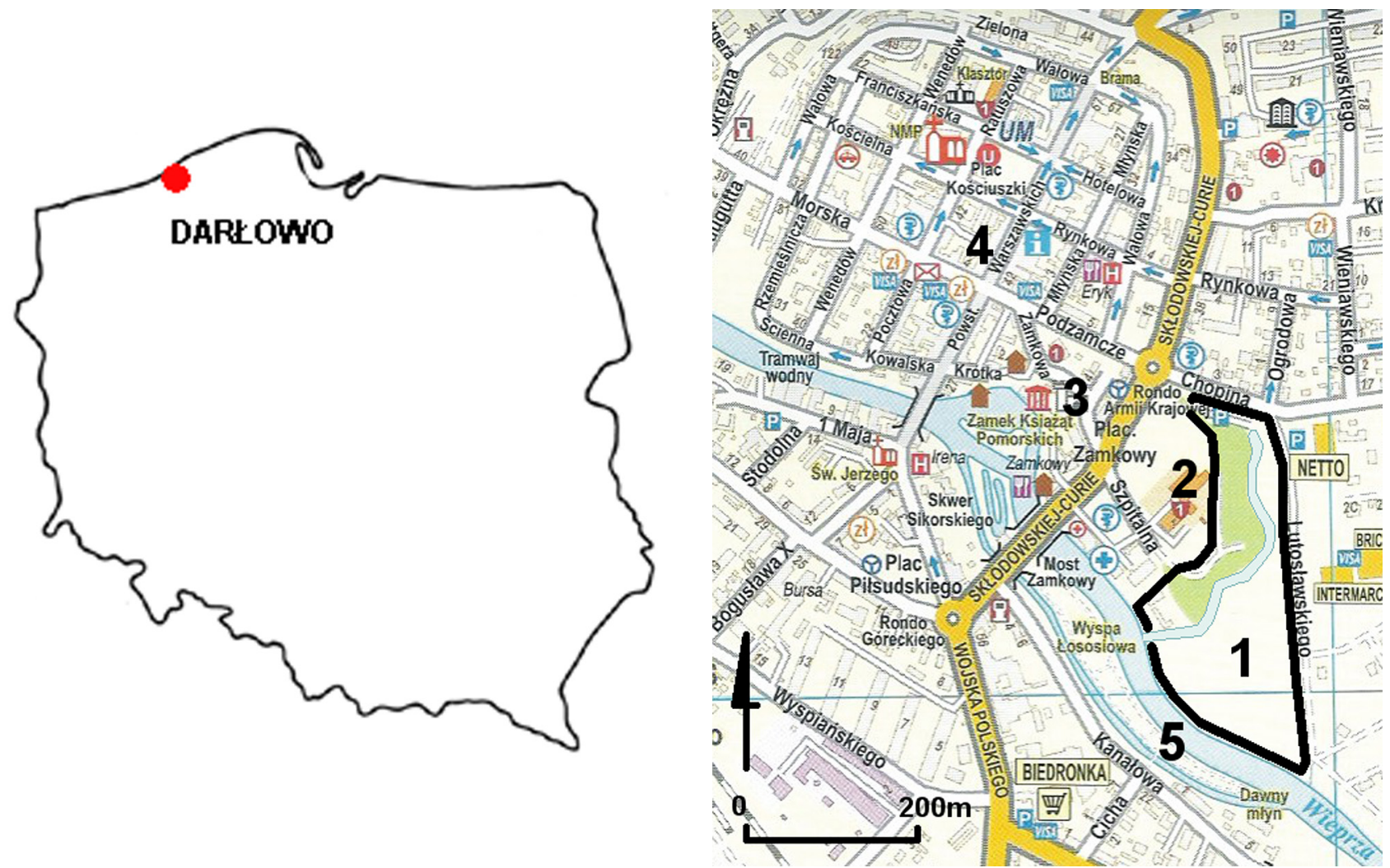

Ryc. 1.1 - Park za Szkołą Morską w Darłowie, 2 - Szkoła Morska, 3 - Zamek Książąt Pomorskich, 4 - śródmieście Darłowa, 5 - rzeka Wieprza

Źródło: opracowanie P. Szumigała, K. Szumigała.

Fig. 1.1 - Park behind the Maritime School in Darłowo, 2 - Maritime School, 3 - Castle of Pomeranian Dukes, 4 - Downtown of Darłowo, 5 - Wieprza River Source: study of P. Szumigała, K. Szumigała.

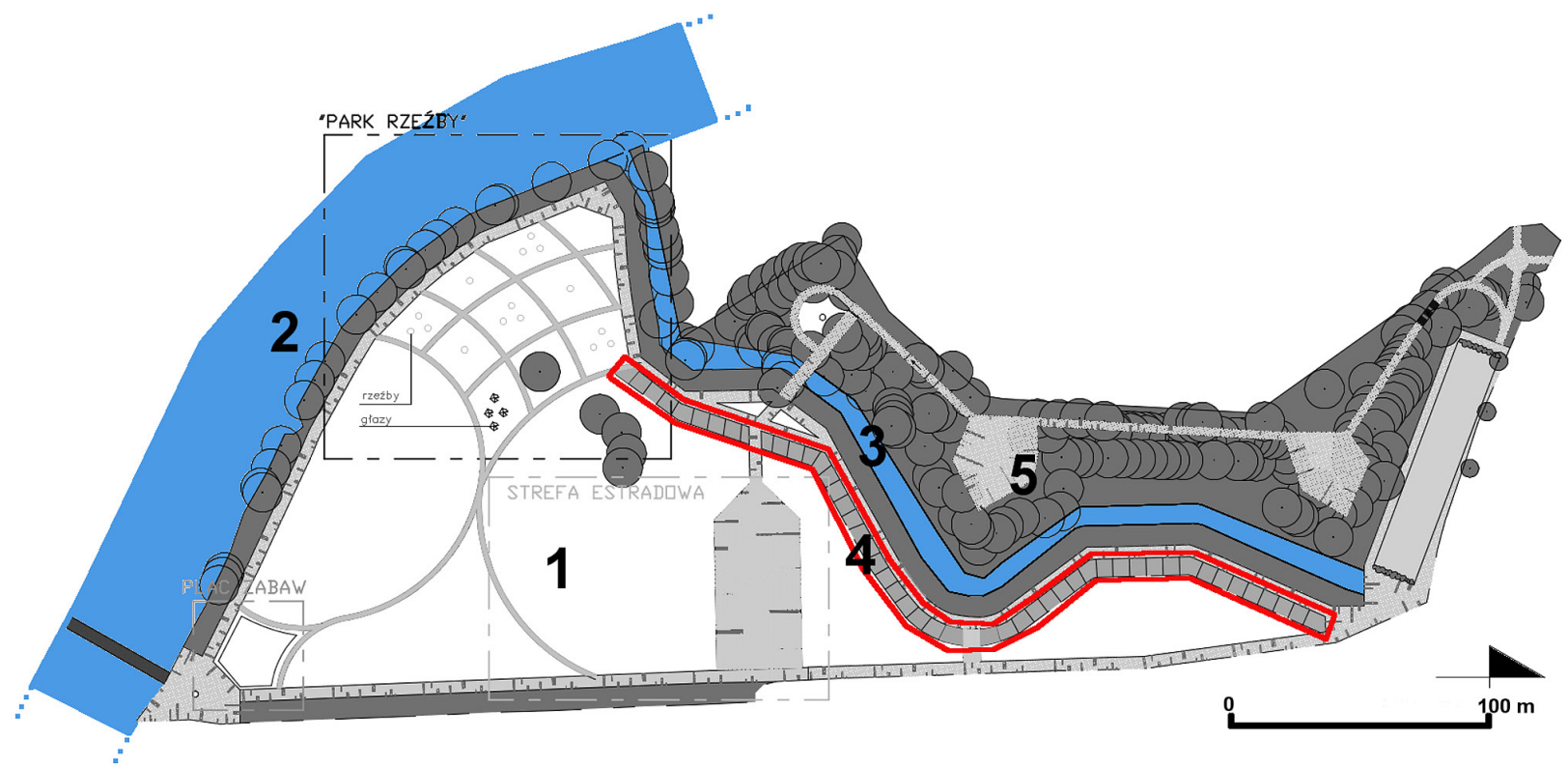

Ryc. 2. Schemat zagospodarowania parku za Szkołą Morską w Darłowie: 1 - park - strefa rekreacji czynnej, 2 - rzeka Wieprza, 3 - fosa, 4 - pas projektowanej zieleni przywodnej - „wstęga”, 5 - istniejący fragment fortyfikacji ziemnych $z$ drzewostanem

Źródło: opracowanie P. Szumigała, K. Szumigała.

Fig. 2. The development scheme of the park behind the Maritime School in Darłowo: 1 - the park - the active recreation zone, 2 - Wieprza River, 3 - the moat, 4 - the stip of designed greenery - the "ribbon", 5 - the existing fragment of the earth fortifications with the stand

Source: study of P. Szumigała, K. Szumigała. 
podziału przestrzeni parku na kilka stref funkcjonalnych o odmiennym charakterze (Szumigata 2012a, b). Istotnym elementem zagospodarowania obszaru parku było odtworzenie przestrzeni o walorach zbliżonych do krajobrazu z czasów historycznych, występującego na przedpolach fortyfikacji w formie obszarów przywodnych (rozlewisk) sąsiadujących z fosą i rzeką Wieprzą. Cechą charakterystyczną tego krajobrazu było występowanie zieleni przywodnej oraz łąkowej terenów otwartych i podmokłych. W tym celu $\mathrm{W}$ projekcie zagospodarowania parku została zaplanowana specjalna strefa w kształcie „wstęgi” pasma zieleni przywodnej usytuowanego wzdłuż kanału fosy wraz ze ścieżką spacerową (ryc. 2). Przez dobór gatunków i kompozycję nasadzeń utworzono fragment przestrzeni o charakterze zarówno ozdobnym, jak i wypoczynkowym. Istotnym aspektem sposobu zagospodarowania tej strefy było nawiązanie do charakteru przestrzeni historycznej we współczesnej formie. W ramach opracowania wykonano plan realizacyjny zagospodarowania parku zaspokajającego potrzeby współczesnego społeczeństwa związane $z$ aktywnym i biernym wypoczynkiem oraz wymagania dotyczace kształtowania krajobrazu przestrzeni publicznych i historycznych.

\section{MATERIAŁ I METODY}

\section{ZAŁOŻENIA KOMPOZYCYJNE PARKU - PODZIAŁ NA STREFY FUNKCJONALNE}

Obszar parku za Szkołą Morską, o powierzchni 4 ha, obejmuje teren ograniczony od północny ulicą Chopina, od południa rzeką Wieprzą, od wschodu ulicą Lutosławskiego, a od zachodu obszarami należącymi do Zespołu Szkół Morskich w Darłowie. Najcenniejszymi elementami parku są historyczne fortyfikacje usytuowane w jego północnej części. Fortyfikacje mają postać ziemnych wałów i bastionów o przebiegu linii łamanej. W miejscach załamania linii przebiegu wału, składającego się $z$ trzech odcinków, są zlokalizowane dwa bastiony ziemne na planie zbliżonym do pięcioboków foremnych. Fortyfikacje porasta dość zwarty i okazały drzewostan, który na prostych fragmentach wału ma postać alei. Fortyfikacje i porastający go drzewostan są zasadniczym elementem panoramy na miasto i Zamek Książąt Pomorskich z kierunków południowego i południowo-zachodniego. Wzdłuż fortyfikacji przebiega w kształcie linii łamanej istniejący fragment starej fosy. Obecnie fosa nie jest już bezpośrednio połączona z rzeką Wieprzą. Zasilana jest wodami spływającymi $z$ wałów i przyległego terenu oraz wodami podskórnymi przesiąkającymi od strony rzeki. Dzięki temu poziom wody $\mathrm{w}$ fosie zmienia się wraz $z$ poziomem wody rzeki Wieprzy. Na poludnie za fosą rozciąga się łąka, z której otwiera się widok na fortyfikacje i Zamek Książąt Pomorskich. Opisane wyżej uwarunkowania historyczne i krajobrazowo-przestrzenne uznano za główne wytyczne kompozycji parku. Zasadniczym założeniem planowanego parku było zachowanie widoku na fortyfikacje, zamek i miasto. W kompozycji parku i w panoramie na miasto zastosowano metodę rekompozycji polegającą na uzupełnieniu i dopełnieniu panoramy elementami pierwszego planu (podstawy panoramy) w postaci strefy nasadzeń zielenią przywodną i łąkową. Elementy te decydują w głównej mierze o stworzeniu terenu zbliżonego charakterem do historycznego krajobrazu otwartego przedpola fortyfikacji. W planie zagospodarowania parku wydzielono część historyczną: fortyfikacje, fosa i strefa zieleni przywodnej wraz ze ścieżką spacerową oraz część rekreacyjną, która składa się z kilku stref funkcjonalnych: rekreacji czynnej, imprez masowych, placu zabaw, strefy wystawienniczej w przestrzeni otwartej i parkingów. Strefa zieleni przywodnej, tzw. „wstęga”, to zasadniczy element części historycznej parku. Stanowi ona uzupełnienie pierwszego planu (podstawy panoramy) i pełni funkcję strefy ozdobnej. W parku zaprojektowano również układ ścieżek obwodowych i wewnętrznych, który pozwala na skomunikowanie ze sobą stref funkcjonalnych. Proponowany system komunikacyjny parku składa się z dróg pieszych i pieszo-jezdnych, umożliwiających obsługę techniczną terenu również $z$ użyciem pojazdów do 3,5 tony i samojezdnego sprzętu mechanicznego. Ścieżki obwodowe mają nawierzchnię utwardzoną z kostki granitowej, natomiast ścieżki wewnętrzne - nawierzchnię żwirową. Uzupełnieniem zagospodarowania parku są elementy małej architektury - ławki, płotki, kosze na odpady, tablice informacyjne i stylowe oświetlenie.

Przedmiotem zaprezentowanych badań jest „wstęga" - pas zieleni przywodnej o powierzchni $1739 \mathrm{~m}^{2}$. W badaniach zastosowano metodę analizy kompozycyjnej ekspozycji widoku krajobrazowego oraz analizę struktur zieleni i zasadę doboru gatunkowego do warunków siedliskowych.

\section{WYNIKI I DYSKUSJA}

\section{ELEMENTY ZAGOSPODAROWANIA STREFY ZIELENI PRZYWODNEJ}

Zieleń parku składa się $z$ istniejącego, gęstego zadrzewienia występującego $\mathrm{w}$ rejonie historycznych ziemnych fortyfikacji i łąki, a także z zieleni projektowanej, którą przewidziano $\mathrm{w}$ postaci ozdobnej „Wstęgi”, składającej się z rodzimych gatunków zieleni przywodnej i terenów podmokłych oraz roślin występujących na innych szerokościach geograficznych. O zastosowaniu w tej kompozycji roślin $z$ innych stref klimatycznych zdecydowały ich pokrój i barwa, które nawiązują do form roślin rodzimych. „Wstęgę” zaplanowano po południowej stronie fosy, tak aby nowa 
Tabela 1. Zestawienie roślin i charakterystyka nasadzeń „wstęgi”

Table 1 . Summary of plants and planting characteristics ribbons

\begin{tabular}{|c|c|c|c|c|c|c|c|}
\hline & & & $\begin{array}{l}\text { Wykaz roślin } \\
\text { List of plants }\end{array}$ & & & & \\
\hline $\mathrm{Nr}$ & Nazwa łacińska & Nazwa polska & Liczba & Więźba & \multicolumn{3}{|c|}{ Powierzchnia $\left(\mathrm{m}^{2}\right)$} \\
\hline No & Latin name & Polish name & Number & Lift & \multicolumn{3}{|c|}{ Area $\left(\mathrm{m}^{2}\right)$} \\
\hline \multicolumn{8}{|c|}{ Krzewy } \\
\hline $1^{*}$ & Salix purpura 'Nana’ L. & wierzba purpurowa & 225 & $1 \mathrm{~m} \times 1 \mathrm{~m}$ & \multicolumn{3}{|c|}{270} \\
\hline \multicolumn{8}{|c|}{ Byliny } \\
\hline $2^{*}$ & Filipendula ulmaria & $\begin{array}{l}\text { wiązówka } \\
\text { błotna }\end{array}$ & 1093 & $7 \mathrm{szt} . / \mathrm{m}^{2}$ & \multicolumn{3}{|c|}{160} \\
\hline $4^{*}$ & Lythrum salicaria & krwawnica pospolita & 865 & $5 \mathrm{szt} . / \mathrm{m}^{2}$ & \multicolumn{3}{|c|}{173} \\
\hline $6^{*}$ & $\begin{array}{l}\text { Polemonium caeruleum } \\
\text { 'Album' }\end{array}$ & $\begin{array}{l}\text { wielosił błękitny (bia- } \\
\text { to kwitnacy) }\end{array}$ & 794 & $7 \mathrm{szt} . / \mathrm{m}^{2}$ & \multicolumn{3}{|c|}{113} \\
\hline $7^{*}$ & Lysimachia punctata & tojeść kropkowana & 1290 & $12 \mathrm{szt} . / \mathrm{m}^{2}$ & \multicolumn{3}{|c|}{108} \\
\hline \multicolumn{8}{|c|}{ Trawy } \\
\hline $3^{*}$ & Miscanthus sacchariflorus & miskant cukrowy & 1920 & $3 \mathrm{szt} . / \mathrm{m}^{2}$ & \multicolumn{3}{|c|}{640} \\
\hline $5^{*}$ & $\begin{array}{l}\text { Spatina pectinata } \\
\text { 'Aureomarginata' }\end{array}$ & spatyna grzebienista & 823 & $3 \mathrm{szt} . / \mathrm{m}^{2}$ & \multicolumn{3}{|c|}{275} \\
\hline \multicolumn{5}{|c|}{ Razem } & \multicolumn{3}{|c|}{1739} \\
\hline \multicolumn{8}{|c|}{ Charakterystyka nasadzeń } \\
\hline $\mathrm{Nr}$ & Nazwa łacińska & Nazwa polska & Wysokość (cm) & Kwitnienie & $\begin{array}{c}\text { Kolor } \\
\text { kwiatostanów }\end{array}$ & $\begin{array}{l}\text { Mrozo- } \\
\text { odporność }\end{array}$ & Gleba \\
\hline \multicolumn{8}{|c|}{ Krzewy } \\
\hline $1^{*}$ & Salix purpura 'Nana' L. & wierzba purpurowa & $180-200$ & III-VI & $\begin{array}{c}\text { biały } \\
\text { (ozdobne pędy) }\end{array}$ & wysoka & $\begin{array}{l}\text { umiarkowana, su- } \\
\text { cha do podmokłej }\end{array}$ \\
\hline \multicolumn{8}{|c|}{ Byliny } \\
\hline $2^{*}$ & Filipendula ulmaria & wiązówka błotna & 200 & VI-VII & biały & wysoka & $\begin{array}{l}\text { wilgotna do pod- } \\
\text { mokłej }\end{array}$ \\
\hline $4^{*}$ & Lythrum salicaria & krwawnica pospolita & 100 & VII-VIII & fioletowy & wysoka & wilgotna \\
\hline $6^{*}$ & $\begin{array}{l}\text { Polemonium caeruleum } \\
\text { 'Album' }\end{array}$ & wielosił błękitny & 60 & VI-VII & biały & wysoka & $\begin{array}{l}\text { umiarkowana su- } \\
\text { cha do podmokłej }\end{array}$ \\
\hline $7^{*}$ & Lysimachia punctata & tojeść kropkowana & 60 & VI-VIII & żółty & wysoka & $\begin{array}{l}\text { umiarkowana su- } \\
\text { cha do podmokłej }\end{array}$ \\
\hline \multicolumn{8}{|c|}{ Trawy } \\
\hline $3^{*}$ & Miscanthus sacchariflorus & miskant cukrowy & 180 & VIII-X & $\begin{array}{l}\text { srebrzysty, } \\
\text { jedwabny }\end{array}$ & wysoka & sucha do wilgotnej \\
\hline $5^{*}$ & $\begin{array}{l}\text { Spartina pectinata } \\
\text { 'Aureomarginata' }\end{array}$ & $\begin{array}{l}\text { spartyna } \\
\text { grzebieniasta }\end{array}$ & 150 & VIII-IX & $\begin{array}{l}\text { dekoracyjne } \\
\text { liście }\end{array}$ & wysoka & $\begin{array}{l}\text { umiarkowana, wil- } \\
\text { gotna do wilgotnej }\end{array}$ \\
\hline
\end{tabular}

*Numeracja roślin odnosi się do oznaczeń na rycinie 3A, B, C - jest to pierwsza cyfra w opisie rabaty.

*Plant numbering refers to the markings in Figures 3A, B, C - this is the first digit in the description of the flowerbeds.

Źródło: opracowali R. Siwiński, P. Szumigała.

Source: study of R. Siwiński, P. Szumigała.
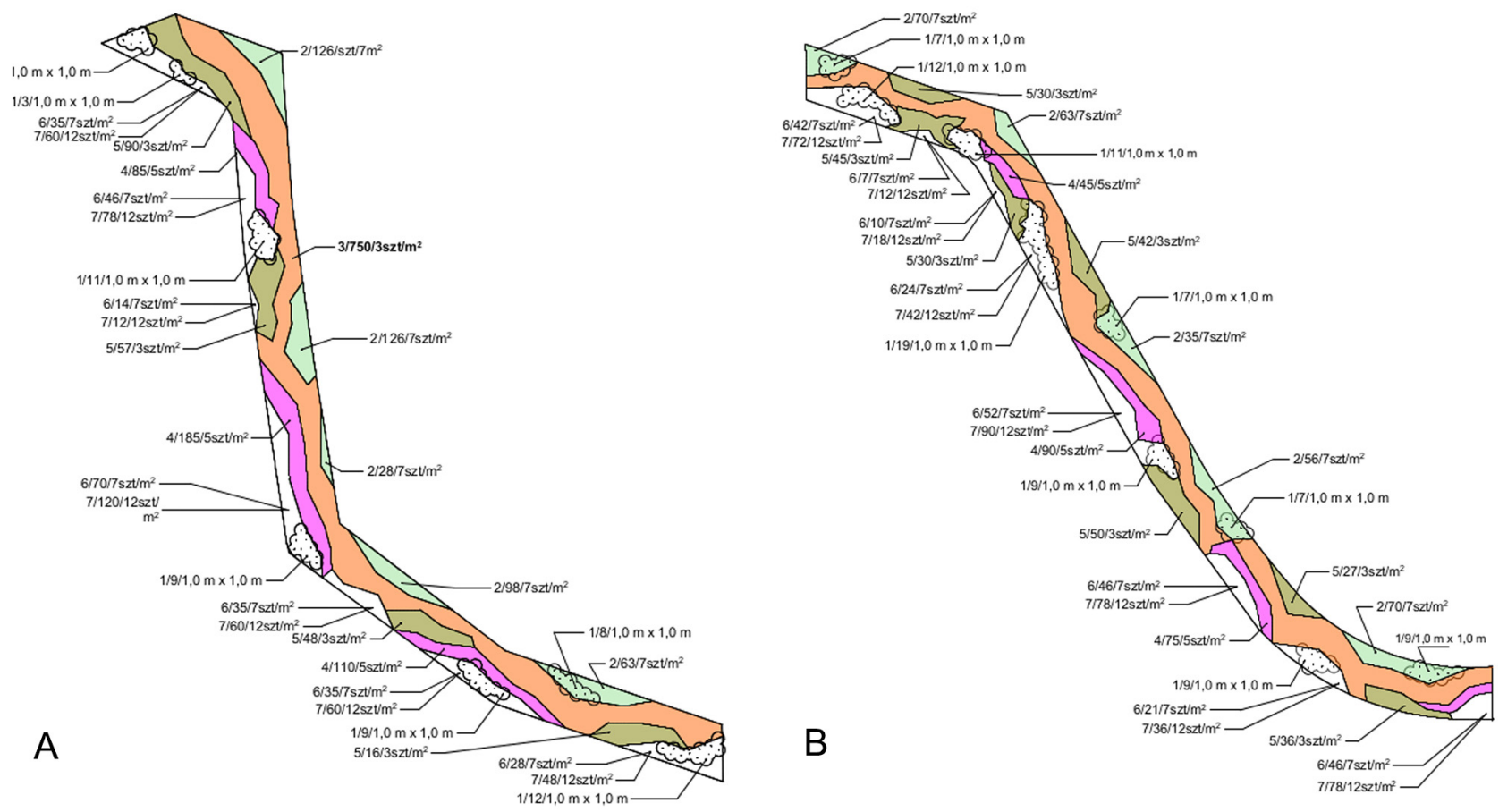


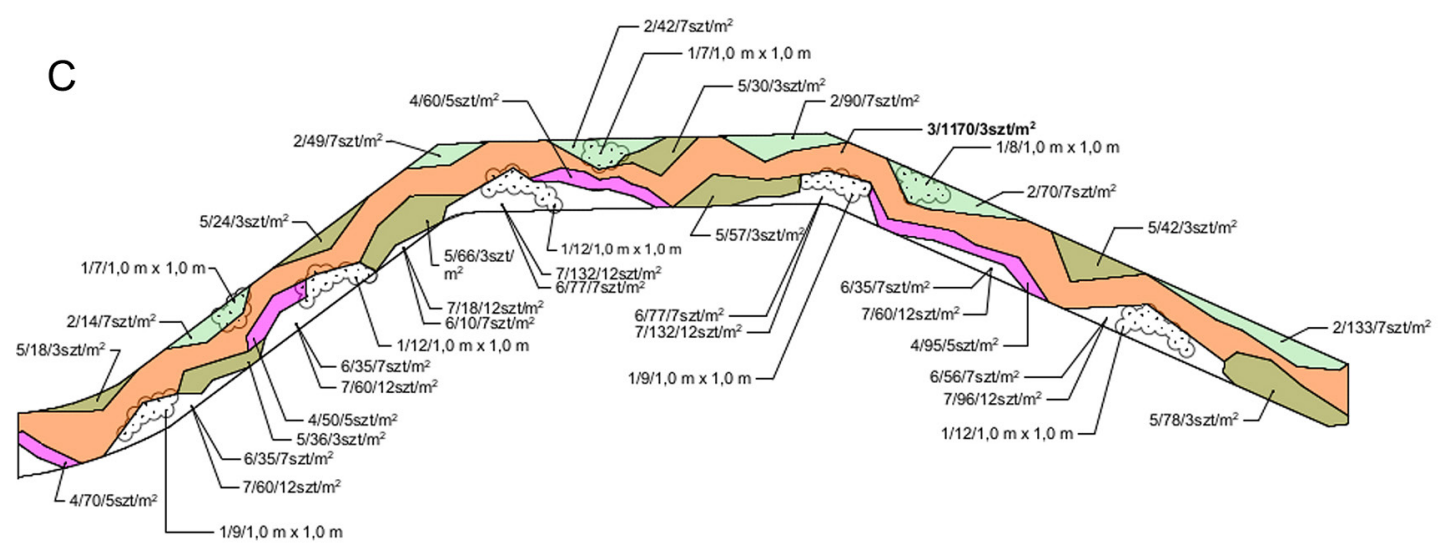

Ryc. 3. Rozkład nasadzeń „wstęgi”: A - część 1, B - część 2, C - część 3

Źródło: opracowanie R. Siwiński.

Fig. 3: Distribution of ribbon plantings: A - part 1, B - part 2, C - part 3

Source: study of R. Siwiński.

roślinność podkreślała w sposób naturalny charakter miejsca oraz nawiązywała do historycznego krajobrazu otwartego i przedpola fortyfikacji. Projektowane rabaty roślinne „wstęgi” tworzą pas terenu wzdłuż kanału, który podkreśla dawny „łamany” układ przestrzenny fosy oraz fortyfikacji, a jednocześnie stanowią kompozycję roślin drugiego piętra, pomiędzy najniżej usytuowaną powierzchnią trawników a najwyższym piętrem - drzewostanem porastającym fortyfikacje. Rośliny zastosowane w kompozycji „wstęgi” są zróżnicowane pod względem wysokości, formy, pokroju i barwy, co nawiązuje do układów roślinności przywodnej i łąkowej występujących w środowisku naturalnym na terenach przywodnych i podmokłych. Projektowana wstęga składa się $\mathrm{z}$ trzech odcinków oddzielonych przejściami dla pieszych (ryc. 3A-C). W kompozycji nasadzeń „wstęgi” zastosowano rośliny, które zestawiono w tabeli 1 i opisano poniżej.

\section{MISKANT CUKROWY (MISCANTHUS SACCHARIFLORUS)}

Miskant cukrowy należy do rodziny Poaceae - wiechlinowate (fot. 1). W stanie naturalnym gatunek występuje na wschód od jeziora Bajkał, głównie w dorzeczu Amuru oraz między Sachalinem a Półwyspem Koreańskim, rośnie również w Japonii. Osiąga wysokość $180 \mathrm{~cm}$. Liście równowąskie, długości $40-60 \mathrm{~cm}$, szerokości do $2 \mathrm{~cm}$, z czerwonobrązowym paskiem wzdłuż środkowego nerwu. Późnym latem liście przebarwiają się na brązowoczerwono. Kwiatostan długości 10-20 cm, srebrzysty, jedwabny, dekoracyjny od sierpnia do zimy. Trawa o niewielkich wymaganiach. Dobrze rośnie na każdej glebie, nawet suchej i jałowej. Silnie się rozrasta, nadaje się więc do większych naturalistycznych nasadzeń (URBAŃSKI 2001).

Fot. 1. Miscanthus sacchariflorus 'Robustus' (fot. P. Urbański) Phot. 1. Miscanthus sacchariflorus 'Robustus' (photo P. Urbański)

\section{SPARTYNA GRZEBIENIASTA (SPARTINA PECTINATA 'AUREOMARGINATA')}

Inną projektowaną $\mathrm{w}$ parku trawą, niższą od miskanta cukrowego, jest spartyna grzebienista, która rośnie w sąsiedztwie tej pierwszej i jest jej dopełnieniem kompozycyjnym (fot. 2).

Roślina o przewieszających się liściach. Należy do rodziny Poacea - wiechlinowate. W warunkach naturalnych rośnie na terenach bagiennych Ameryki Północnej. Wyrasta do $150 \mathrm{~cm}$. Tworzy gęste kępy z krótkimi rozłogami. Liście o ostrych brzegach długości do $60 \mathrm{~cm}$, szerokości $2 \mathrm{~cm}$, zwężające się w długi szpic.

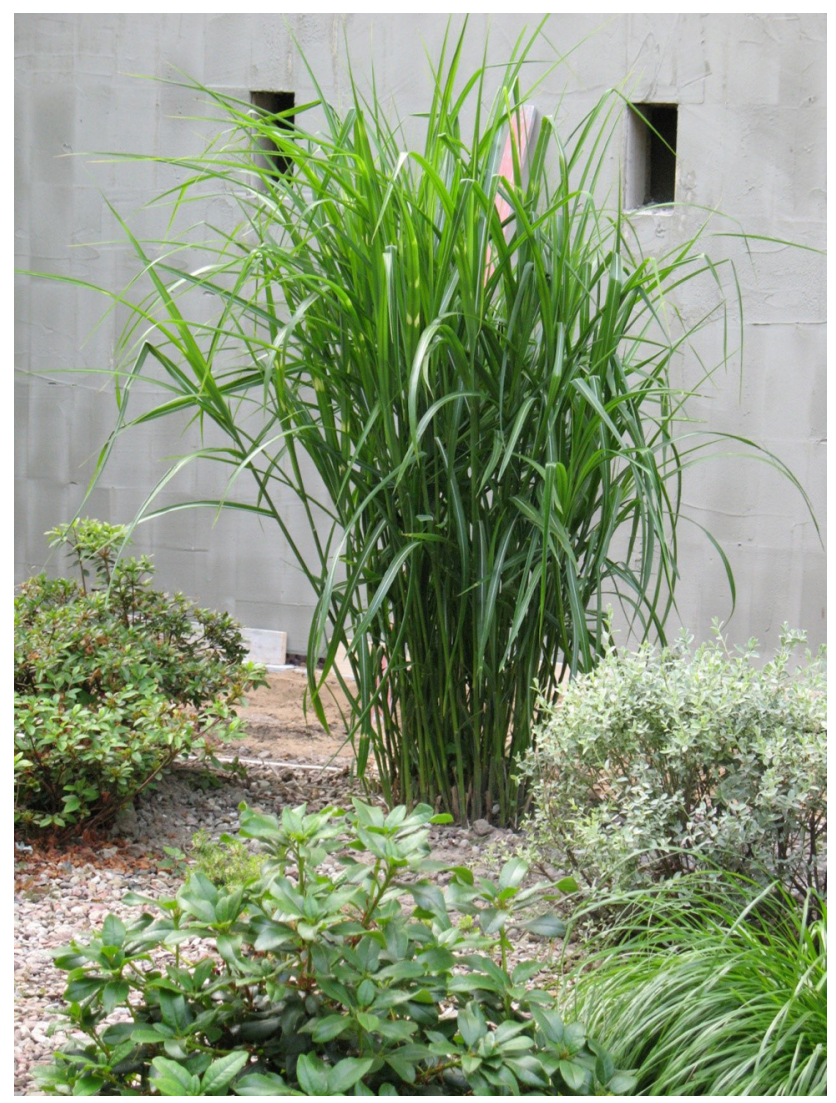




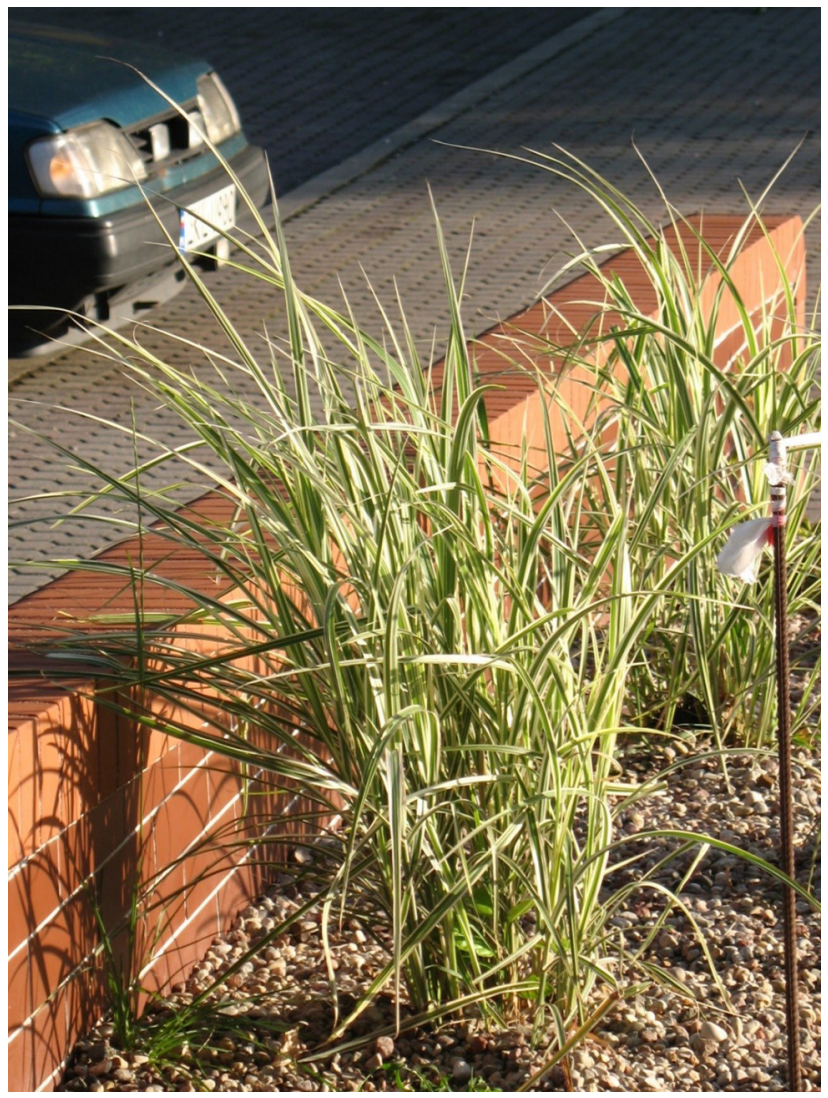

Fot. 2. Spartina pectinata 'Aureomarginata' (fot. P. Urbański) Phot. 2. Spartina pectinata 'Aureomarginata' (photo P. Urbański)

U odmiany 'Aureomarginata’ liście charakteryzują się wąskim, żółtym obrzeżeniem. Są odporne na warunki atmosferyczne. Po zaschnięciu pozostają ozdobne przez całą zimę, więc należy je ścinać dopiero na wiosnę. Kwiatostany długości $20-40 \mathrm{~cm}$ nie mają wartości dekoracyjnej. Nadaje się do wysadzania w większych grupach na glebach niekoniecznie bagiennych, a także do obsadzania fragmentów parków o charakterze naturalnym. Spartyna wykazuje dużą tolerancję na zróżnicowane warunki siedliskowe, rośnie nawet na glebie jałowej, znosi suszę i zacienienie (URBAŃSKI 2001).

\section{KRWAWNICA POSPOLITA (LYTHRUM SALICARIA)}

Należy do rodziny Lythraceae - krwawnicowate. Występuje na całej półkuli północnej i w Australii, pospolita także na terenie Polski. Łodygi rośliny są pojedyncze lub z nielicznymi, krótkimi odgałęzieniami, wyprostowane, owłosione, mają około 100 cm wysokości. W sprzyjających warunkach mogą osiągnąć wysokość $150 \mathrm{~cm}$. Dolne liście są sercowate, górne - łodygowe - mają kształt wąskolancetowaty i są ułożone naprzeciwlegle po 2 lub 3 w okółkach. Karminoworóżowe kwiaty są zebrane w długie (do 30 $\mathrm{cm}$ ) kłosowate kwiatostany, bardzo chętnie odwiedzane przez motyle i pszczoły. Kwitnienie przypada

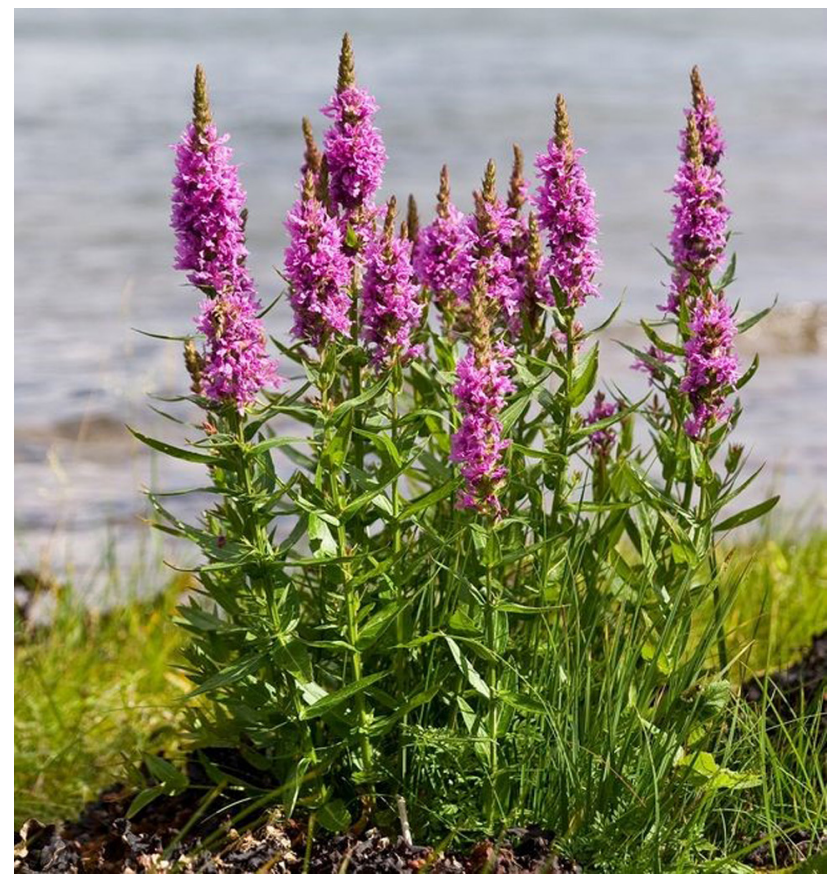

Fot. 3. Lythrum salicaria Źródło/Source: [3].

na okres lipca i sierpnia. Lythrum salicaria sadzi się na stanowiskach słonecznych, nadwodnych lub na wilgotnych, próchnicznych rabatach, ponieważ w takich warunkach czuje się najlepiej. Na glebach suchych nie wyrasta do typowej wysokości (fot. 3).

\section{TOJEŚĆ KROPKOWANA (LYSIMACHIA PUNCTATA)}

Należy do rodziny Primulaceae - pierwiosnkowate. Gatunek występuje w południowo-wschodniej części

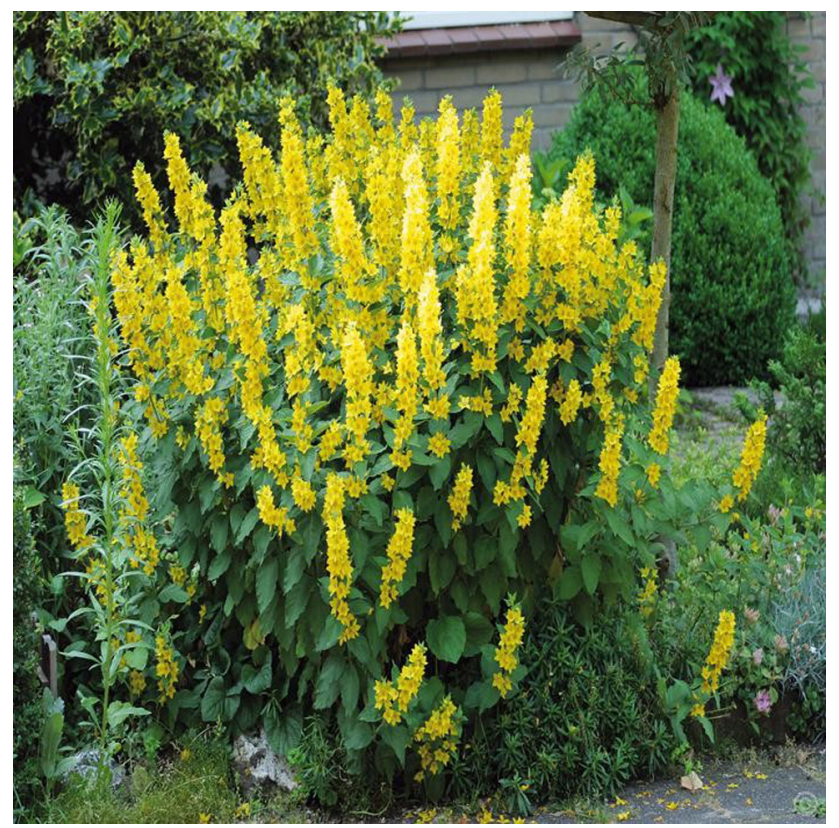

Fot. 4. Lysimachia punctata

Źródło/Source: [4]. 
kraju, w miejscach raczej wilgotnych. Ma krótkie podziemne rozłogi, pędy wzniesione, owłosione, kanciaste, słabo rozgałęzione. Odmiana 'Variegata' osiąga wysokość $60 \mathrm{~cm}$, ma liście biało obrzeżone, jajowate lub lancetowate, długości około $7 \mathrm{~cm}$, osadzone okółkowo na całym pędzie. Żółte kwiaty średnicy około $2 \mathrm{~cm}$ wyrastają po kilka z kątów górnych liści, tworząc długie, ulistnione grona. Płatki kwiatów są pokryte drobnymi, gruczołkowatymi włoskami. Tojeść odznacza się długim (od czerwca do sierpnia) i obfitym kwitnieniem. Lysimachia punctata jest jedną z najważniejszych bylin używanych do obsadzania naturalistycznych przestrzeni, nadaje się również na rabaty. Sprawdza się jako roślinność towarzysząca zbiornikom wodnym, dobrze znosi okresowe zalanie wodą. Jest rośliną mrozoodporną i długowieczną. Równie dobrze czuje się w słońcu, jak i na ocienionych stanowiskach, pod warunkiem, że podłoże jest żyzne, najlepiej gliniaste lub ilaste, średnio wilgotne do wilgotnego (fot. 4).

\section{WIELOSIŁ BŁEKITNY (POLEMONIUM CAERULEUM 'ALBUM')}

Należy do rodziny Polemoniaceae - wielosiłowate. Rodzima bylina, występująca na mokrych łąkach i w zaroślach. Wielosił rośnie $\mathrm{w}$ Polsce na naturalnych stanowiskach, jest pod ochroną. Forma 'Album' osiąga wysokość ok. $60 \mathrm{~cm}$. Ma wyprostowane, kanciaste, puste, dołem gładkie, w górnej części gruczołowane łodygi. Liście pierzaste, dolne na ogonkach, górne siedzące, z 17-27 podługowato-lancetowatymi siedzącymi listkami barwy ciemnozielonej. Szeroko dzwonkowate białe kwiaty z żółtymi pylnikami są zebrane $\mathrm{w}$ wierzchołkowe wiechy i nadają się do cięcia. Kwitnie od czerwca do lipca. Kwiaty wielosiłu są chętnie odwiedzane przez pszczoły i inne błonkówki. Wielosił błękitny nadaje się do sadzenia na rabatach, w założeniach naturalistycznych i na wilgotnych

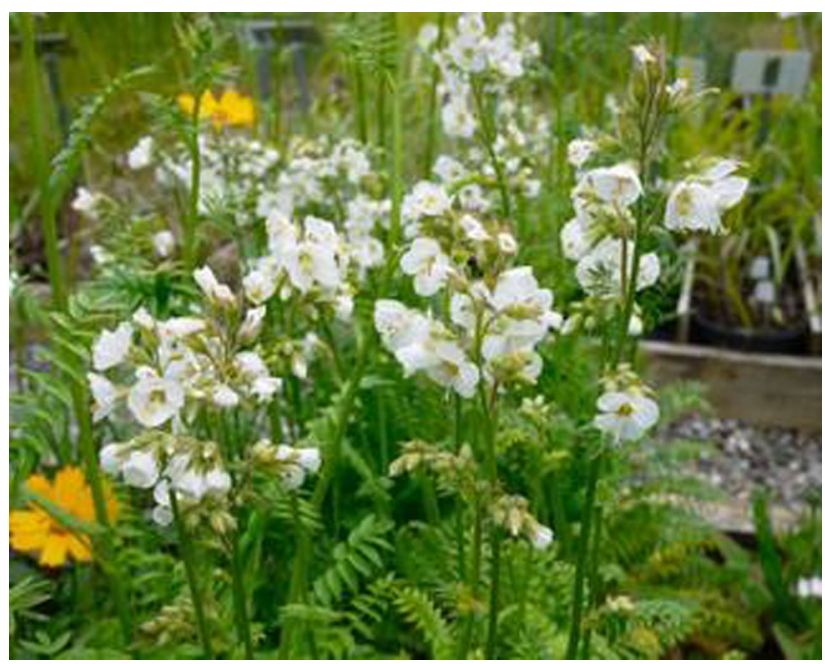

Fot. 5. Polemonium caeruleum 'Album'

Źródło/Source: [5]. łąkach lub między krzewami, nad brzegiem wody. W medycynie ludowej ziele wielosiłu stosowano jako środek uspokajający. Bylina najlepiej rośnie na glebach próchnicznych i żyznych, kwaśnych lub lekko kwaśnych, przepuszczalnych, na stanowiskach wilgotnych, nie lubi suszy (fot. 5).

\section{WIĄZÓWKA BŁOTNA (FILIPENDULA ULMARIA)}

Należy do rodziny Rosaceae - różowate. Jest to roślina rodzima, występująca na wilgotnych łąkach oraz nad brzegami wód. Osiąga wysokość do $200 \mathrm{~cm}$. Łodygi ma obficie ulistnione, liście złożone, $z$ listkiem wierzchołkowym większym od szerokojajowatych, zaostrzonych listków bocznych. Żółtawobiałe, pachnące kwiaty są zebrane w duże podbaldachy. Kwitnie od czerwca do sierpnia. Nadaje się do naturalistycznych nasadzeń nad brzegami wód, razem z krwawnicami i innymi podobnymi bylinami. Jest łatwa do uprawy, wymaga jedynie dość wilgotnego stanowiska, szczególnie w okresie wyrastania pędów kwiatostanowych. Przy odpowiedniej wilgotności gleby znosi nasłonecznienie, ale lepiej uprawiać ją w półcieniu (fot. 6).

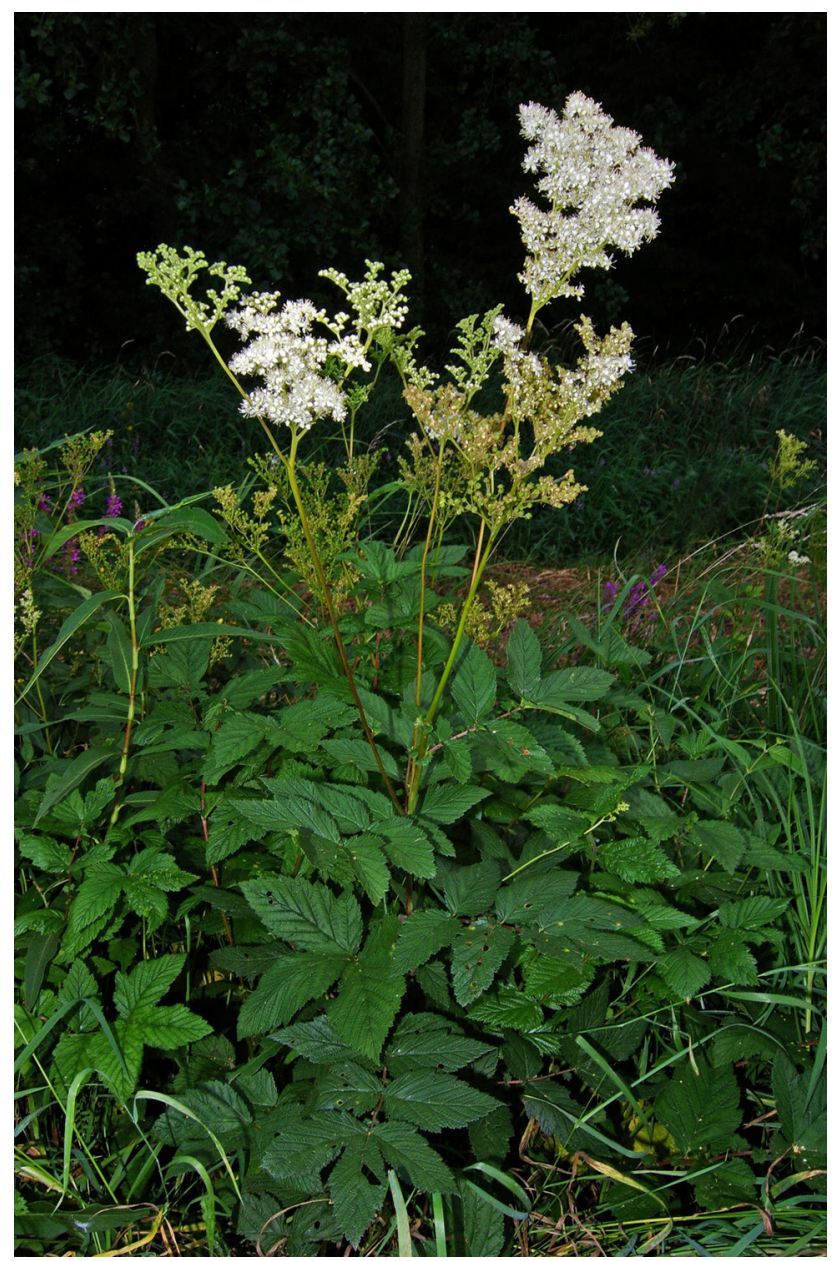

Fot. 6. Filipendula ulmaria

Zródło/Source: [6]. 


\section{WIERZBA PURPUROWA 'NANA' (SALIX PURPUREA 'NANA')}

Kulisty, gęsty krzew z licznymi, delikatnymi pędami o brązowoczerwonej barwie. Dorasta do $2 \mathrm{~m}$. Liście lancetowate, srebrzystoszare. Niewymagający, dobrze rośnie na glebach umiarkowanie suchych i całkowicie mokrych, od średnio kwaśnych do całkiem alkalicznych. Toleruje mrozy i upały. Stanowisko słoneczne do lekko cienistego. Wymaga cięcia.

Do nasadzeń przewidziano rośliny dostosowane do istniejących warunków klimatyczno-glebowych, o szczególnych walorach dekoracyjnych, zróżnicowanym pokroju i różnych barwach, zarówno liściaste, jak i iglaste - zimozielone oraz zrzucające liście na zimę (fot. 7).

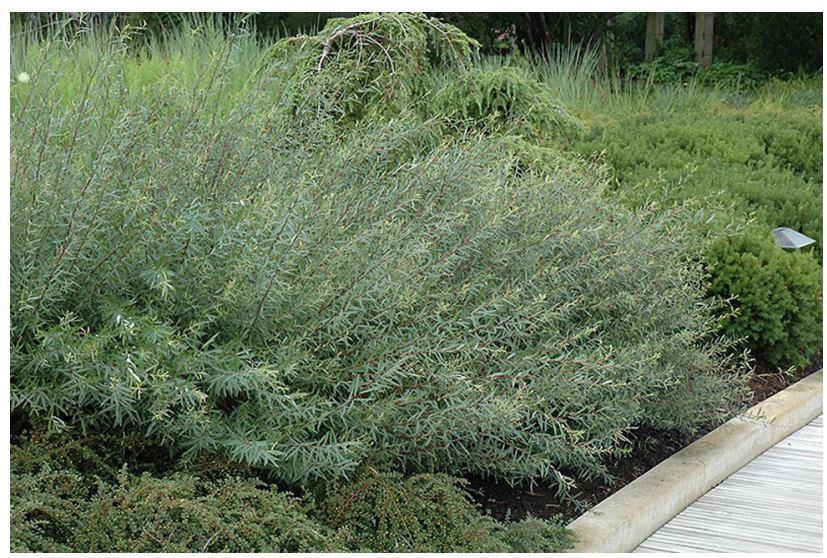

Fot. 7. Salix purpurea 'Nana'

Źródło/Source: [7].

\section{PODSUMOWANIE}

Zastosowanie roślinności przywodnej i łąkowej oraz zakomponowanie jej siedlisk $\mathrm{w}$ formie pasa terenu naśladującego przebieg fosy pozwala na zrealizowanie projektu przestrzeni parku miejskiego o walorach krajobrazu historycznego, które są zbliżone do naturalnych. W Parku za Szkołą Morską w Darłowie udało się również wkomponować pozostałości historycznych fortyfikacji wraz $z$ nowymi nasadzeniami $\mathrm{w}$ program ogólnodostępnych funkcji użytkowych służących mieszkańcom miasta. Projekt zagospodarowania parku i program działań inwestycyjnych pozwala sądzić, że to ważne dziedzictwo kulturowe, jakim jest fragment krajobrazu historycznego, będzie mogło nadal istnieć w przestrzeni Darłowa. Dzięki możliwości pozyskania funduszy (unijnych i innych) możliwa będzie jego ochrona oraz wykorzystanie atrakcyjnych form zieleni i walorów terenu dla zorganizowania przestrzeni miejskiej o indywidualnym charakterz nawiązującym do historii tego miejsca.

\section{LITERATURA}

Miejscowy plan zagospodarowania przestrzennego miasta Darłowo - uchwała nr XLVII/445/06 Rady Miejskiej w Darłowie z dnia 27 marca 2006 r.

Szumigata P. (2012a): Projekt koncepcyjny zagospodarowania parku za Szkołą Morską w Darłowie. Maszynopis. Urząd Miasta w Darłowie.

Szumigata P. (2012b): Projekt realizacyjny zagospodarowania parku za Szkołą Morską w Darłowie. Maszynopis. Urząd Miasta w Darłowie.

URBAŃSKI P. (2001): Trawy ozdobne, turzyce i sity. PWRiL, Warszawa.

Wytyczne Wojewódzkiego Konserwatora Zabytków w Koszalinie

\section{ŹRÓDŁA INTERNETOWE}

[3]

https://www.google.pl/imgres?imgurl=http:// budujesz.info//pliki/image/artykuly/byliny/duze/krwawnica-pos polita 3327 .jpg \& imgrefurl=http:// budujesz.info/artykul/krwawnica-pospolita-uprawa-odmiany-i-zastosowanie, 1128.htm$1 \& \mathrm{~h}=650 \& \mathrm{w}=611 \& \mathrm{tbnid}=$ CDtEIHfWHbIn$\mathrm{fM}: \& \mathrm{tbnh}=186 \& \mathrm{tbnw}=174 \& \mathrm{usg}=$ _eluZd VBtjql_LcEWu-H7hPdSzg\%3 D\&vet $=10 \mathrm{a}-$ hUKEwiOrNjvt9_YAhWow6YKHdutAhsQ B0IiAEwCg..i\&docid $=$ Dad52Tar1T-W6M\&itg $=1 \&-$ client $=$ firefox-b\&sa $=\mathrm{X} \& v e d=0$ ahUKEwiOrNjvt9_YAhWow6YKHdutAhsQ_B0IiAEwCg (dostęp: 7.01.2018)

[4]

https://www.google.pl/imgres? imgurl=https://albamar.pl/9353-home_default/tojesc-kropokowana-lysimachia-punctata.jpg\&imgrefurl=https:// albamar.pl/byliny/918-tojesc-kropokowana-lysimachia-punctata. html \&h $=270 \& w=270 \& \mathrm{t}-$ bnid=0r34QG6I2Ied8M: \& tbnh $=186 \&$ tbn$\mathrm{w}=186 \&$ usg $=$ _q $1 \mathrm{vW}$ WQBHxLG-gG69NSomqATBAxA\%3D\&vet = 10ahUKEwjG4ZLXuN_ YAhWFDSwKHVBLDioQ BOIjQEwCg..i\&docid $=$ WwBSqn 1 oeBgN2M\&itg $=1 \&$ client $=$ firefox-b\&sa $=$ X\&ved =0ahUKEwjG4ZLXuN_YAhWFDSwKHVBLDioQ BOIjQEwCg\#h $=270 \overline{\text { \&img- }}$ dii $=$ yfzp0epKp9gtM:\&tbnh=186\&tbn$\mathrm{w}=186 \& \mathrm{vet}=10$ ahUKEwjG4ZLXuN_YAhWFDSwKHVBLDioQ_BOIjQEwCg..i\&w $=270$ (dostęp: 7.01.2018)

[5]

https://www.google.pl/search?q=Polemonium +caeruleum + f. + album \&client $=$ firefox-b\&d$\mathrm{cr}=0 \& \mathrm{tbm}=\mathrm{isch} \&$ source $=\mathrm{iu} \& \mathrm{ictx}=1 \&-$ fir $=03 \mathrm{cZrZSzX}$ thxsM\%253 A \%252CoioJ f0 7GL5PUM\%252C_\&usg = _dTfKJHFj5o9f9jFxlizqnHjqVSs\%3D\&sa $=\bar{X} \& v e d=0 a-$ 
hUKEwjewvudud_YAhUDCpoKHQG2BHsQ9QEIOzAE\#imgrc $=03$ cZrZSzXthxsM: (dostęp: 7.01.2018)

[6]

https://www.google.pl/imgres?imgurl=https:// upload.wikimedia.org/wikipedia/commons/ thumb/c/c7/FilipendulaUlmaria.jpg/1200px-FilipendulaUlmaria.jpg\&imgrefurl $=$ https://pl.wikipedia.org/wiki/Wi\%25C4\%2585z\%25C3\%25B-

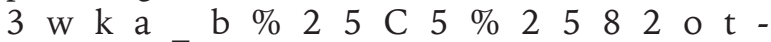
$\mathrm{n}$ a $\& \mathrm{~h}=1838 \& \mathrm{w}=12008 \mathrm{t}$ bnid $=$ OI51 unYSLv4U2M: \&tbnh $=186 \&$ tbn$\mathrm{w}=121$ \&usg = _a7gGn5diOpnPz7ya9Mf3Vmnqyuc\%3D\&vet $=10$ ahUKEwiE Pnbud YAhVBsywKHV8JAZwQ BOIiAEwCg...i\&docid=WoLALa9D5pfSeM\&itg = $1 \&$ client $=$ firefox-b\&sa $=$ X\&ved=0ahUKEwiE_Pnbud_YAhVBsywKHV8JAZwQ BOIiAEwCg ('̄ostęp: $\overline{7} .01 .2018)$
[7]

https://www.google.pl/search?q=Salix + purpurea $+\% 27$ Nana $\% 27 \&$ client $=$ firefox-b\&d$\mathrm{cr}=0 \& \mathrm{tb} \mathrm{m}=\mathrm{isch} \&$ source $=\mathrm{iu} \& \mathrm{ict} \mathrm{x}=1 \&$ fir $=$ C 5 r0m GxXuzcpYM\%253 A \% 252CpNOyF 5 _ePuu $28 \mathrm{M} \% 252 \mathrm{C} \&$ \& s g $=$ W L q m H R z h 5 E S W h l I s N of O v M k y2eA\%3D\&sa =X\&ved =0ahUKEwjepOGJut_YAhVLhaYKHQgABM0Q9QEIOTAC\#imgrc=C5r0mGxXuzcpYM: (dostęp: 7.01.2018)

For citation: Szumigata P., URBaŃSKi P., SiWińSKi R., Walerzak M., Szumigata K. (2018): Zieleń przywodna $\mathrm{W}$ zagospodarowaniu parku za Szkołą Morską w Darłowie. Steciana 22(1): 3-11. doi:10.12657/steciana.022.003. 